European

Thyroid Journal

\title{
A Warm Welcome to the ETA Annual Meeting in the Wonderful City of Santiago de Compostela
}

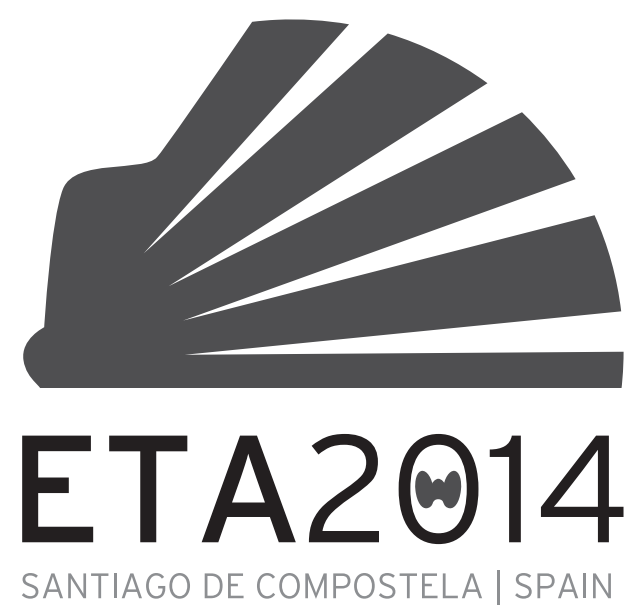

The 38th Annual Meeting of the European Thyroid Association will be held on September 6-10, 2014 at the Palacio de Congresos in Santiago de Compostela, Galicia, Spain. On behalf of the Local Organizing Committee, I wish you a warm welcome to this meeting.

The ETA Executive Committee and the Local Organizing Committee have worked very hard to put together an appealing scientific program and to ensure a confortable location for this event. Using the past experience, we have maintained the well consolidated scheme for our daily activities. We will start with several pre-conference activities on Saturday, including an Ultrasonography Course, the ICCIDD meeting, the Spanish Society Satellite Symposium, a Basic Thyroid Course, the ETA-CRN meeting and the TFI Patient Forum, followed by the Opening Ceremony. Six Industry-Sponsored Satellite Symposia have been allocated during the meeting. 
Scientific presentations will include oral and poster presentations of accepted abstracts, young investigator sessions, symposia, meet-theexpert sessions and award prizes. Regarding the poster sessions, this year we have introduced a state-of-art electronic poster system which, we hope, will be easy and practical to use.

Santiago de Compostela is an ancient city where medicine and science are two of the main driving forces. Our Cathedral presides over the old city where the Hostal de los Reyes Catolicos was created to treat the many pilgrims arriving to the city for centuries. On the other hand, we cannot forget that Santiago is a university town full of students and street life. You are welcomed to extend scientific discussions after the sessions on the terraces and take advantage of the lively atmosphere to increase thyroid scientific networking and collaborations. You can even arrive as a pilgrim in an activity organized by the patients' associations.

In the Middle Ages around half a million pilgrims came to Santiago every year, in spite of Erasmus of Rotterdam recommendation: 'You have to become crazy to walk to Santiago'. Famous pilgrims have been Carlo Magno (778 DC), El Cid (1064), King Louis VII of France (1154 DC), Francisco de Assisi (1214 DC), the Prince of Wales James III of Scotland and England (1719), the Naruhito Prince from Japan (2013) among many popes, kings, presidents and famous actors. Goethe wrote that the European spirit has been developed around the pilgrimage to Santiago.

With this premise, we are confident that many members, and nonmembers, will arrive in Santiago and will actively participate in the meeting's activities contributing to make of the ETA 2014 another of many successful meetings of our association. We look forward to seeing you here in September 2014.

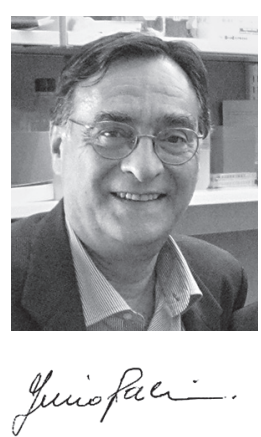

Furio Pacini

President of the ETA
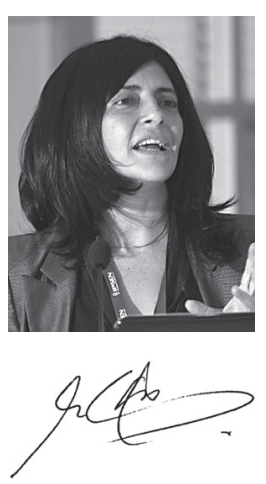

Clara V. Alvarez

President of the Local Organizing Comittee 